УДК 342.9 (477)

DOI https://doi.org/10.32838/TNU-2707-0581/2020.5/11

\title{
Лемеха P.I.
}

Запорізький національний університет

\section{ІСТОРІЯ СТАНОВЛЕННЯ ТА РОЗВИТКУ ІНСТИТУТУ МИТНИХ РЕЖИМІВ В УКРАЇНI}

У науковій публікаиї̈ оосліджується історія становлення та розвитку інституту митних режсимів в Україні. Зазначається, що митний режим є комплексом взаємопов'язаних правових норм, щзо відповідно до заявленої мети переміщення товарів через митний кордон України визначають митну процедуру щзодо иих товарів, їхній правовий статус, умови оподаткування і обумовлюють їх використання після митного оформлення.

Проведене дослідження історії становлення та розвитку інституту митних режимів в Україні дозволяє сформулювати висновок про те, щьо періодизацію історії митної справи в Украӥни можливо умовно розподілити на 7 етапів: I - докиївський період в історії митної справи на украӥнських землях (V cm. до н. е. - VIII cm. н.е е.); II - період Київської Русі та монголо-татарського панування (XI - XVII cm.); III - період запорізького козачтва - Гетьманщини (XVI cm. - перша половина XVIII cm.); IV - період входження українських земель до Російської імперії (кінець XVIII - початок XX ст.); V-митна справа в Украӥні в радянську добу (1917-1991 рр.); VI-період становлення та розвитку митної справи в період розбудови незалежної украӥнської держави (з 1991-2012 рр.); VII - сучасний період, пов'язаний з активними прочесами євроінтеграчії, прийняттям чинного Митного кодексу України, приведенням національного законодавства у сфері митної справи у відповідність до норм і принципів права Європейського Союзу (2012 p. - дотепер).

Зазначається, щчо історичний досвід свідчить про рачіональність та доиільність окремого функиіонування Державної податкової служби та Державної митної служби України, які, незважаючи на значну кількість спільних рис їх правової природи та призначення, виконують окремі важлливі функиї держави: адміністрування податків та адміністрування митних зборів, переміщення товарів і транспортних засобів через митний кордон Украйни відповідно. Практика об'єднання та успішного функиіонування митної та податкової служби існує в низиі європейських держав (Данія, Естонія, Угорщина, Ірландія, Латвія, Португалія, Іспанія, Румунія, Словаччина, Словенія та ін.), однак в Україні така реформа призвела до глибокої адміністративно-інституиійної кризи, наслідки котрої й дотепер негативним руйнівним чином визначають функиіонування національної митної системи.

Формулюється висновок про те, щзо дослідження історії становлення та розвитку інституту митних режимів в Украӥні є основою для подальшого вдосконалення чинного національного законодавства та юридичної практики, розроблення перспективного законодавства у сфері правового регулювання митних режимів.

Ключові слова: засади, митні режсими, історія становлення, етапи розвитку, митна справа, переміщення, товари, правовий статус, митні процедури, митні відносини, адміністративне право, публічна адміністрачія.

Постановка проблеми. Дослідження будьякого правового явища чи процесу обов'язково має грунтуватися на детальному аналізі історії його виникнення та розвитку, адже поява нових суспільних відносин, які потребують правового регулювання, завжди зумовлена певними чинниками та історичними подіями. Науковий аналіз зазначених чинників та подій дозволяє зрозуміти правову природу відповідного явища чи процесу, а також сформулювати практичні рекомендації щодо вдосконалення їхніх право- вих засад та відповідної юридичної практики. Митний режим є комплексом взаємопов'язаних правових норм, що відповідно до заявленої мети переміщення товарів через митний кордон України визначають митну процедуру щодо цих товарів, їхній правовий статус, умови оподаткування й обумовлюють їх використання після митного оформлення. Таким чином, інститут митних режимів $є$ комплексним міжгалузевим інститутом митного права, який регулює досить велику сферу суспільних відносин, які склалися 
історично й мають свої особливості правового врегулювання. Дослідження історії становлення та розвитку митних режимів в Україні дозволить виявити позитивний історичний досвід регулювання митних відносин на українських землях i сформулювати пропозиції щодо актуальних напрямів удосконалення чинного та формування перспективного законодавства у сфері митної справи, чим обгрунтовується як теоретичне, так і практичне значення даної публікації.

Аналіз останніх досліджень і публікацій. Питання адміністративно-правового регулювання митних відносин в Україні досліджуються в роботах фахівців у сфері адміністративного права, серед яких роботи О. Бандурки, В. Бевзенка, Н. Білак, М. Віхляєва, Н. Губерської, С. Гусарова, Р. Калюжного, Т. Коломоєць, В. Колпакова, А. Комзюка, О. Кузьменко, В. Курила, Д. Лук'янця, Д. Лученка, П. Лютікова, М. Мельника, Р. Мельника, О. Миколенка, Я. Назарової, Н. Нижник, Д. Приймаченка, С. Стеценко, М. Тищенка, О. Чуприни, А. Школика та інших учених-адміністративістів. 3 останніх досліджень слід відзначити дисертаційну роботу М. Мельника «Інститут митних режимів у митному праві України» [1]. Проте питання історії становлення та розвитку інституту митних режимів в Україні досліджено фрагментарно, більшою мірою в рамках більш загальних тем, що актуалізує проведення даного дослідження.

Методологія даного дослідження грунтується на комплексному поєднанні філософських законів діалектики (єдності та боротьби протилежностей, переходу кількісних змін в якісні та прийому «заперечення заперечення») і метафізики, загальнонаукових та спеціально-юридичних методів дослідження (методології порівняльного правознавства, методу юридичного моделювання тощо), принципів об'єктивності та історизму. Зокрема, закон переходу кількісних змін в якісні наочно простежується в історії розвитку правового регулювання митних відносин, коли збільшення кількості та ускладнення митних відносин зумовлює необхідність їх якісного правового врегулювання, прийняття якісно нових систематизованих нормативно-правових актів. Принцип історизму вимагає від дослідника враховувати ті історичні фактори та події, які зумовили необхідність правового врегулювання митних відносин у певній країні, враховуючи як об'єктивні, так і суб'єктивні чинники, піддаючи їх критичному аналізу.

Постановка завдання. Метою наукової публікації є дослідження історії становлення та роз- витку інституту митних режимів в Україні як комплексного міжгалузевого інституту митного права, виникнення якого зумовлено певними історичними та економічними чинниками.

Виклад основного матеріалу. Виникнення митної справи прямо пов'язано з появою державності на українських землях, виникненням приватної власності та торгівлі. 3 розвитком економічних відносин поступово відбувається соціальне розшарування суспільства та виникає окремий клас купців, які займаються торгівлею товарами не лише в межах території перших державних утворень, але й $з$ представниками інших країн, розвиваючи міжнародну торгівлю. Водночас представники політичної влади шукають нові джерела поповнення державної скарбниці, запроваджуючи нові податки та збори, включаючи мита.

У Київській Русі за правління правнука Ольги князя Ярослава Мудрого було складено перший писемний звід законів - знамениту «Руську правду», якою детально регламентувалася система оподаткування. Основою грошових надходжень були мита і штрафи. Більшість становили торговельні мита: «вага» і «міра» - за зважування і вимір; «мит»-за провезення товарів через міські застави; «перевіз» - перевезення товарів через річку. «Гостинне» $\mathrm{i}$ «торгове» мито стягувалося за право мати склади і проводити торжища [2].

Таким чином, поява митних режимів експорту та імпорту, справляння мита за переміщення товарів через кордон були зумовлені реальним економічним чинником - потребою наповнення державної казни, що і натепер є одним 3 основних завдань Державної митної служби України (яка, у відповідності до покладених на неї завдань, організовує та здійснює ведення обліку й адміністрування митних та інших платежів, контроль за справлянням яких законом покладено на Держмитслужбу, забезпечує контроль за своєчасністю, достовірністю, повнотою їх нарахування та сплати в повному обсязі платниками податків до відповідного бюджету під час переміщення товарів через митний кордон України та після завершення операцій з митного контролю та митного оформлення; проводить відповідно до законодавства документальні перевірки дотримання вимог законодавства 3 питань державної митної справи, в тому числі своєчасності, достовірності, повноти нарахування та сплати у повному обсязі митних платежів, і зустрічні звірки [3]).

Науковці зазначають, що періодизацію історії митної справи в України можливо умовно розпо- 
ділити на 6 етапів: I - докиївський період в історії митної справи на українських землях (V ст. до н. е. - VIII ст. н. е.); II - період Київської Русі та монголо-татарського панування (XI - XVII ст.); III - період запорізького козацтва - Гетьманщини (XVI ст. - перша половина XVIII ст.); IV - період входження українських земель до Російської імпеpiї (кінець XVIII - початок XX ст.); V - митна справа в Україні в радянську добу (1917-1991рр.); VI - період становлення та розвитку митної справи в період розбудови незалежної української держави (1991-2012 рр.) [4-6; 8].

Доцільним вбачається доповнення наведеної вище періодизації VII-м сучасним етапом, пов'язаним 3 активними процесами євроінтеграції, прийняттям чинного Митного кодексу України, приведенням національного законодавства у сфері митної справи у відповідність до норм та принципів права Європейського Союзу (2012 р. - дотепер).

Перші згадки про митні платежі на території сучасної України належать до IX ст. Саме за цих часів були підписані дві торгівельні угоди з Візантією, які були названі «договори з греками». Вони не тільки зумовлювали зовнішні зв'язки стародавньої Русі, а й фіксували подальший розвиток зовнішньоторговельної (митної) справи.

На початку другої половини ХI ст. на Русі був час князівських міжусобиць, через що відбувався спад торговельних взаємовідносин 3 іншими державами. Князі проводили особисту митну політику в межах своїх володінь та створювали власну систему митних зборів, що мала на меті власне збагачення. За таких умов Стародавня Русь протрималась до першої третини XIII ст. та занепала під нападами орд Батия. Монголо-татари за часи свого правління ввели внутрішнє торгове мито (тамгу), яке стягувалось 3 усіх товарів, що продавались [6, с. 508].

Отже, історичний досвід доводить необхідність існування публічної мети встановлення та функціонування системи митних зборів, які повинні використовуватися публічною адміністрацією на благо всього суспільства та сприяти розвитку міжнародної торгівлі.

Період запорізького козацтва розпочався 3 XV ст. Активно розвивалась торгівля з Польщею, Литвою, Південною Росією у XVI - XVIII ст. Козаки у 1649 р. уклали договір із султаном Туреччини, за яким Туреччина надавала купцям право вільно перетинати Чорне та Середземне моря, користуючись усіма їхніми портами в будь-який час, без ускладнень спілкуватися з купцями мате- рикових та річкових міст, здійснювати продаж, купівлю й обмін товарів, а також будувати в портах склади, а козаки зобов'язувались не нападати на Османську Імперію. Така ситуація зумовила появу на Запорізькій Січі своїх митних порядків. Наприклад, якщо корабель, не доходячи версту до Січі, витримував 20 діб так званого «карантину», то міг увійти до бухти безмитно. За часи правління Січчю Б. Хмельницьким відбулося врегулювання митних спорів між Україною та Росією. Він установив в Універсалі 1654 р. такси митних оплат, так званої «індукти», з привізного краму. Поборці державних прибутків називалися індукторами (або екзакторами). Їм дозволялося від уряду побирання (збирання) митних та горілчаних поборів. У перший час після Переяславської ради 1654 р. Україна мала своєрідне (якого не мала жодна інша адміністративна одиниця Росії) козацько-старшинське самоврядування, військо, суд, податкову систему, митні кордони. Однак за умовами «Переяславських статей» 1659 р. за гетьмана Ю. Хмельницького Україна була позбавлена права на самостійні зовнішні відносини [4, с. 35].

До кінця XVII ст. на українських землях, які входили до складу Російської держави, склалася система митних установ зі своїми штатами. У період державних переворотів із 1725 по 1762 роки митна політика характеризувалася непослідовністю. У 1724 р. Катерина І видала наказ про «Покровительський митний тариф» (товари, які ввозилися іноземними купцями, обкладалися митом, російські купці могли вивозити свої товари без перешкод) [4, с. 35-36]. Але в 1726 р. і в 1728 р. були підписані російсько-англійські та російсько-прусські договори, які встановлювали режим взаємного митного добробуту. Митний тариф 1731 р. цілком відмінив «Покровительський митний тариф». Реформа 1753 р. внесла зміни в митні заклади, ліквідувалися внутрішні митниці. У зв'язку з ростом контрабанди у 1754 р. була створена прикордонна варта, набирались команди митних кінних об'іждчиків. Митним тарифом $1767 \mathrm{p}$. були встановлені мита на продукти, які виготовлялися в країні на низькому рівні або в незначній кількості та які ввозились і були конкурентоспроможними з російськими. Були засновані нові митниці в Одесі, Севастополі, Ростові-на-Дону та інших містах. Посилювалась охорона митних кордонів [7, с. 44-45].

У 1864 р. в Міністерстві фінансів був організований департамент митних зборів для управління митними закладами. Підвищувалась якість діяльності митного контролю у сфері боротьби 
3 контрабандою. У 1877-1887 pр. наступила політика обмеження ввозу іноземних товарів. У 1876 р. в 10-ти містах було прийнято рішення брати митні збори в золотій валюті. Митний тариф 1891 р. підвищив ввізні мита на іноземні машини, хімічні товари, бавовну, цукор, чавун, рейки. Проте кордон не був забезпечений належним митним контролем [4, с. 38-39; 6, с. 508].

Митний контроль у найбільш наближеному до сучасного вигляді почав діяти після Жовтневого перевороту 1917 р., коли в Декреті було встановлено дозвіл на ввезення та вивезення товарів, прописано правила провозу товарів через кордон, визначено поняття контрабанди. Однак слід ураховувати, що за тих часів митна служба розвивалась в умовах громадянської війни, голоду, господарської розрухи та товарного дефіциту. У період з 1920 р. по 1922 р. проходила організація митної справи, в Україні і Харкові був створений відділ митного контролю, на кордонах функціонували митні заклади 3-х видів (митниці, митні нагляди та митні пости). 12 листопада 1922 р. було створено Українське відділення Головного митного управління (2 лютого 1934 р. воно було ліквідовано). 14 грудня 1924 р. Президія ЦВК СРСР затвердила Митний статут СРСР, а 19 грудня 1928 р. постановою ЦВК і РНК СРСР був уведений у дію Митний кодекс СРСР [4, с. 39-40].

5 травня 1964 р. Президія Верховної Ради СРСР затвердила новий Митний кодекс СРСР $[7$, c. 46]. Таким чином, в радянський період на території України була створена досить розгалужена система митного контролю, проте слід зауважити, що це не сприяло розвитку міжнародної торгівлі та активному функціонуванню митних режимів транзиту, експорту та імпорту, адже радянська економіка була відмежована від світових ринків так званою «залізною завісою», функціонувала відособлено за відсутності адекватної конкуренції та 3 акцентом на військовопромислове виробництво.

3 проголошенням незалежності України виникла об'єктивна потреба регулювання митних відносин в умовах вільної ринкової економіки з відкритими для іноземних товарів кордонами.

25 червня 1991 р. Верховна Рада України прийняла Закон «Про митну справу в Україні», в якому проголосила, що Україна «як суверенна держава самостійно створює власну митну систему і здійснює митну справу». 12 грудня 1991 р. Верховна Рада України прийняла Постанову «Про введення в дію Митного кодексу України» [6, с. 509].

13 березня 2012 року Верховною Радою України було прийнято чинний Митний кодекс Укра- їни, V розділ якого присвячений митним режимам (глави 12-26). У ньому досить детально прописані загальні положення щодо митних режимів, наведено їх класифікацію та окремо прописані особливості кожного.

Історія вітчизняної митниці незалежної України розпочинається 3 реорганізації Управління державного митного контролю при Раді Міністрів УРСР та утворення на його основі Державного комітету митного контролю України відповідно до постанови Кабінету Міністрів Української РСР «Про порядок реалізації Закону УРСР «Про перелік міністерств та інші центральні органи державного управління Української УРСР» № 12 від 24 травня 1991 р. Незабаром Указом Президента України № 1 від 11 грудня 1991 р. було створено Державний митний комітет України, який фактично стає першим центральним органом державної виконавчої влади в митній сфері, підпорядковуючись Кабінету Міністрів України [8, с. 6].

Після розпаду СРСР митна система України успадкувала 26 митниць, котрі були розміщені в орендованих приміщеннях, та 49 митних постів. Станом на 1991 р. чисельність працівників митних органів становила близько 2,5 тисяч осіб. В умовах становлення молодої держави ключовими проблемами на той час були відсутність розробленої якісної нормативно-правової бази, кваліфікованих та досвідчених фахівців, розвиненої мережі місцевих митних органів, належного матеріально-технічного забезпечення, що значною мірою стримувало розвиток зовнішньоекономічної діяльності вітчизняних суб' єктів господарювання $[8$, с. 6$]$.

Вирішення означених проблем було законодавчо врегульовано в першому Митному кодексі України № 1970-XII від 12 грудня 1991 р. та Законі України «Про митну справу» № 1262-XII від 25 червня 1991 р. Відповідно до положень Кодексу національна митна політика була спрямована на формування ринкової економіки та активізацію зовнішньоекономічної діяльності суб'єктів господарювання.

Ще одним важливим нормативно-правовим документом, котрий визначив засади митно-тарифного регулювання зовнішньоекономічної діяльності, став Закон України «Про єдиний митний тариф» № 2097-XII від 5 лютого 1992 р.

Згідно з Указом Президента України «Про Державну митну службу України» № 1145/96 від 29 листопада 1996 р. було створено новий однойменний центральний орган виконавчої влади в митній сфері на базі Державного митного комітету України [8, с. 6-7]. 
Відповідно до Положення про Державну митну службу України, затвердженого Указом Президента України № 582/2011 від 12 травня 2011 р., діяльність центрального органу виконавчої влади в митній сфері координувалась Кабінетом Міністрів України через Міністра фінансів. При цьому Державна митна служба втратила повноваження щодо формування державної політики в галузі митної справи, а лише мала право вносити пропозиції в цій сфері.

На підставі Указу Президента України «Про деякі заходи 3 оптимізації системи центральних органів виконавчої влади» № 726/2012 від24 грудня 2012 р. було утворено Міністерство доходів і зборів, яке створювалося шляхом реорганізації Державної митної служби України та Державної податкової служби України. Науковці зазначають, що практика об'єднання та успішного функціонування митної та податкової служби існує в низці європейських держав (Данія, Естонія, Угорщина, Ірландія, Латвія, Португалія, Іспанія, Румунія, Словаччина, Словенія та ін.), однак в Україні така реформа призвела до глибокої адміністративноінституційної кризи, наслідки котрої і дотепер руйнівним чином визначають функціонування національної митної системи $[8$, с. 7].

Міністерство доходів і зборів України функціонувало близько 2-х років та відповідно до Постанови Кабінету Міністрів України № 160 від 21 травня 2014 р. було реорганізовано в Державну фіскальну службу України, діяльність якої координувалась Кабінетом Міністрів України [8, с. 8].

18 грудня 2018 р. було прийнято постанову Кабінету Міністрів України № 1200 «Про утворення Державної податкової служби України та Державної митної служби України», згідно 3 якою були утворені Державна податкова служба України та Державна митна служба України шляхом поділу Державної фіскальної служби. У вказаній постанові визначено, що Державна митна служба $\epsilon$ центральним органом виконавчої влади, діяльність якого спрямовується та координується Кабінетом Міністрів України через Міністра фінансів, і який реалізує державну митну політику, державну політику у сфері боротьби з правопорушеннями під час застосування митного законодавства.

Постановою Кабінету Міністрів України від 6 березня 2019 року № 227 були затверджені положення про Державну податкову службу України та Державну митну службу України, якими визначені актуальні завдання та повноваження зазначених служб.
Таким чином, публічна адміністрація в особі Кабінету Міністрів України фактично дійшла висновку про раціональність та доцільність окремого функціонування Державної податкової служби і Державної митної служби України, які, незважаючи на значну кількість спільних рис їхньої правової природи та призначення, виконують окремі важливі функції держави (адміністрування податків та адміністрування митних зборів, переміщення товарів і транспортних засобів через митний кордон України відповідно).

Таким чином, в історії розвитку державної митної системи України слід виділити п'ять ключових етапів за організаційно-структурним принципом. Зокрема, перший етап розвитку національної митної системи в умовах суверенної держави пов'язаний зі створенням та функціонуванням Державного митного комітету України (1991-1996 рр.); другий етап можна ототожнити 3 діяльністю Державної митної служби України (1996-2012 рр.); третій етап в історії розвитку національної митної системи стосується функціонування митних органів у структурі Міністерства доходів і зборів України (2012-2014рр.); четвертий етап пов'язаний насамперед із реорганізацією Міністерства доходів і зборів у Державну фіскальну службу України, до складу якої ввійшли митні органи (2014-2018рр.) [8, с. 8]; п’ятий етап пов'язаний зі створенням окремих структур Державної податкової та Державної митної служби України шляхом реорганізації (поділу) Державної фіскальної служби України (з 2018 р. й дотепер).

Висновки. Проведене дослідження історії становлення та розвитку інституту митних режимів в Україні дозволяе сформулювати висновок про те, що періодизацію історії митної справи в України можливо умовно розподілити на 7 етапів: I - докиївський період в історії митної справи на українських землях (V ст. до н. е. - VIII ст. н. е.); II - період Київської Русі та монголо-татарського панування (XI - XVII ст.); III - період запорізького козацтва - Гетьманщини (XVI ст. - перша половина XVIII ст.); IV - період входження українських земель до Російської імперії (кінець XVIII - початок XX ст.); V - митна справа в Україні в радянську добу (1917-1991рp.); VI - період становлення та розвитку митної справи в період розбудови незалежної української держави (1991-2012рр.); VII - сучасний період, пов'язаний 3 активними процесами євроінтеграції, прийняттям чинного Митного кодексу України, приведенням національного законодавства у сфері митної справи у відповідність до норм та принципів права Європейського Союзу (з 2012 р. - дотепер). 
В історії розвитку державної митної системи України слід виділити п'ять ключових етапів: створення та функціонування Державного митного комітету України (1991-1996рр.); другий етап, пов'язаний із діяльністю Державної митної служби України (1996-2012рр.); третій етап, який характеризувався функціонуванням митних органів у структурі Міністерства доходів і зборів України (2012-2014рр.); четвертий етап, пов'язаний насамперед із реорганізацією Міністерства доходів і зборів у Державну фіскальну службу України, до складу якої ввійшли митні органи (2014-2018рр.), п’ятий етап, пов'язаний зі створенням окремих структур Державної податкової та Державної митної служби України шляхом реорганізації (поділу) Державної фіскальної служби України (з 2018 р. й дотепер).
Таким чином, історичний досвід свідчить про раціональність і доцільність окремого функціонування Державної податкової та Державної митної служб України, які, незважаючи на значну кількість спільних рис їхньої правової природи та призначення, виконують окремі важливі функції держави: адміністрування податків та адміністрування митних зборів, переміщення товарів і транспортних засобів через митний кордон України відповідно.

Дослідження історії становлення та розвитку інституту митних режимів в Україні $\epsilon$ основою для подальшого вдосконалення чинного національного законодавства і юридичної практики, розроблення перспективного законодавства у сфері правового регулювання митних режимів.

\section{Список літератури:}

1. Мельник М. В. Інститут митних режимів в митному праві України : дис. ... канд. юрид. наук : спец. 12.00.07 «Адміністративне право і процес; фінансове право; інформаційне право»; Міжрегіональна академія управління персоналом. Київ, 2016. 251 с.

2. Руська правда - податковий кодекс Київської Русі. Вісник: офіційно про податки. URL: http://www.visnuk.com.ua/ru/pubs/id/1787

3. Положення про Державну митну службу України, затверджене постановою Кабінету Міністрів України від 6 березня 2019 р. № 227. URL: https://www.kmu.gov.ua/npas/pro-zatverdzhennya-polozhen-proderzhavnu-podatkovu-sluzhbu-ukrayini-ta-derzhavnu-mitnu-sluzhbu-ukrayini

4. Дубініна А., Сорокіна С., Зельніченко О. Митна справа : підручник. Київ : Центр учбової літератури, 2010. $320 \mathrm{c}$.

5. Історія митної діяльності: Україна в європейському контексті: наукове видання / авт. кол.: К.М. Колесников (керівник авторського колективу) та ін. Одеса : Пласко, 2010. 541 с.

6. Основні аспекти становлення та розвитку митної справи України. Науковий вісник Миколаївського наиіонального університету ім. Сухомлинського. Глобальні та національні проблеми економіки. 2018. Випуск 23. С. 506-511. URL: http://global-national.in.ua/archive/23-2018/98.pdf

7. Митна справа : підручник / А. Крисоватий та ін. ; за ред. А. Крисоватого. Тернопіль : ВПЦ «Екон. думка ТНЕУ», 2014. 540 с.

8. Мельник О. Г., Адамів М. Є., Тодощук А. В. Історія розвитку митної системи України: ключові проблеми та здобутки в умовах європейської інтеграції. Економіка та держава. 2018. № 10. С.4-9. URL: http://www.economy.in.ua/pdf/10_2018/3.pdf

\section{Lemekha R.I. HISTORY OF FORMATION AND DEVELOPMENT OF THE INSTITUTE OF CUSTOMS REGIMES IN UKRAINE}

The scientific publication is devoted to the history of the formation and development of the institute of customs regimes in Ukraine. It is noted that the customs regime is a set of interrelated legal norms that, in accordance with the stated purpose of moving goods across the customs border of Ukraine, determine the customs procedure for these goods, their legal status, tax conditions and determine their use after customs clearance.

It is noted that the study of any legal phenomenon or process must be based on a detailed analysis of the history of its origin and development, because the emergence of new social relations that require legal regulation is always due to certain factors and historical events.

The study of the history of formation and development of the institute of customs regimes in Ukraine allows us to conclude that the periodization of the history of customs in Ukraine can be divided into 7 stages: $I$ - the period of formation and development of customs before the formation of Kievan Rus in Ukrainian land (V century BC-VIII century AD); II - the period of Kievan Rus and Mongol-Tatar rule (XI-XVII centuries); III - the period of the Zaporozhian Cossacks - Hetmanate (XVI century - the first half of the XVIII century); 
$I V$ - the period of entry of Ukrainian lands into the Russian Empire (late XVIII - early twentieth century.); $V$ - customs in Ukraine during the Soviet era (1917-1991); VI - the period of formation and development of customs in the period of development of the independent Ukrainian state (from 1991-2012); VII - the modern period associated with the active processes of European integration, the adoption of the current Customs Code of Ukraine, bringing national legislation in the field of customs in line with the norms and principles of European Union law (2012 - present).

It is noted that historical experience testifies to the rationality and expediency of separate functioning of the State Tax Service and the State Customs Service of Ukraine, which, despite a large number of common features of their legal nature and purpose, perform certain important functions of the state: tax administration and movement of goods and vehicles across the customs border of Ukraine, respectively. The practice of unification and successful functioning of the customs and tax service exists in a number of European countries (Denmark, Estonia, Hungary, Ireland, Latvia, Portugal, Spain, Romania, Slovakia, Slovenia, etc.), but for Ukraine such a reform has led to a deep administrative-institutional crisis, the consequences of which still have a negative destructive effect on the functioning of the national customs system.

It is concluded that the study of the history of formation and development of the institution of customs regimes in Ukraine is the basis for further improvement of existing national legislation and legal practice, development of promising legislation in the field of legal regulation of customs regimes.

Key words: principles, customs regimes, history of formation, stages of development, customs business, movement, goods, legal status, customs procedures, customs relations, administrative law, public administration. 